\title{
MIND MAPPING IN TEACHING WRITING
}

\author{
Mukmin $^{1}$, Handrini Afriyanti ${ }^{2}$ \\ ${ }^{1}$ PBI FKIP UM Luwuk, ${ }^{2}$ PBI FKIP UM Luwuk \\ Email: mukminnayya@gmail.com ${ }^{1}$, handrini.isini@gmail.com ${ }^{2}$
}

\begin{abstract}
Abstrak
Tujuan dari penelitian ini adalah untuk mengetahui apakah kemampuan siswa-siswa dalam menulis teks deskripsi menggunakan peta pikiran di Madrasah Aliyah Negeri 1 Banggai dapat meningkat atau tidak dan untuk mengetahui bagaimana peta pikiran meningkatkan kemampuan siswa-siswa dalam menulis. Penelitian ini menggunakan penelitian quasi eksperimen dengan menggunakan non equivalen desain. Populasi pada penelitian ini adalah semua siswa-siswa kelas sepuluh di Madrasah Aliyah Negeri 1 Banggai. Sampelnya adalah kelas X Ipa 1 dan X Ipa 2 dan terdiri dari 35 dan 34 siswa. Instrumen pada penelitian ini adalah tes tulis. Jenis-jenis tes adalah tes awal dan tes akhir. Nilai rata-rata dari tes awal di kelas eksperimen adalah 41 dan nilai rata-rata pada tes akhir di kelas eksperimen adalah 83. Nilai rata-rata dari tes awal di kelas kontrol adalah 37.35 dan nilai rata-rata pada tes akhir di kelas kontrol adalah 47.65. Dari kalkulasi pada thitung lebih tinggi dari tabel. Hasil pada thitung adalah 18.80 sedangkan $t_{\text {tabel }}$ pada tingkat signifikansi 0.05 adalah 1.66792. Jika nilai $t_{\text {hitung }}>t_{\text {tabel, }}$, itu berarti bahwa Ha diterima. Itu menunjukkan bahwa perbandingan pada $t_{\text {hitung }} d a n t_{\text {tabel }}$ adalah $18.80>$ 1.66792. Dengan kata lain hipotesis alternatif terbukti. Ini diasumsikan bahwa teknik peta pikiran dapat meningkatkan kemampuan siswa dalam menulis teks deskripsi.
\end{abstract}

Kata kunci: Kemampuan Menlis; Teks Deskriptive; Peta Pikiran.

\section{Abstract}

The objective of this research is to know whether the students' ability in writing descriptive text using mind mapping in Madrasah Aliyah Negeri 1 Banggai can improve or not and to know how mind mapping improve the students' ability of writing. This research was quasi experimental research by using non-equivalent design. The population of this research were all of the tenth grade students' in Madrasah Aliyah Negeri 1 Banggai. The sample were $X$ science 1 and $X$ science 2 and consist of 35 and 34 students. The instrument of this research was written test. The kinds of test were pre-test and post-test. The mean of pre-test score in experimental class is 41 and the mean of post-test in experimental class is 83. The mean of pre-test score in controlled class is 37.35 and the mean of post-test in controlled class is 47.65. From the calculation of $t_{\text {counted }}$ was higher than $t_{\text {table, }}$ the result of $t_{\text {counted }}$ is 18.80 meanwhile $t_{\text {table }}$ in the degree of significance 0.05 is 1.66792. If the $t_{\text {counted }}>t_{\text {table, }}$, it means that $H_{a}$ is accepted. It shows that the comparison of $t_{\text {counted }}$ and $t_{\text {table }}$ is $18.80>1.66792$. In the other words the alternative hypothesis is proven. It assumed that mind mapping technique can improve the students' ability of writing descriptive text.

Keywords: Writing Ability; Descriptive Text; Mind Mapping. 


\section{Introduction}

Writing is one of the important language skills because writing is a English subject compulsory for students. Furthermore, writing is one of communication tools, it means students use the language to express their feeling, thought and idea in the written form. Writing is most difficult language skill because it is considered as a most complicated language skill to be learned compared to other language skills. In writing process students always deal with the process arranging words into sentences and putting sentences into paragraph until they can create a piece of written text.

In Fact, writing is difficult especially in an academic context. Writing is productive skill that require specialized skills. Therefore, it can be understood that errors usually occur in writing. Error in writing can be form of grammar, vocabulary, punctuation, etc. Based on the researcher's while doing an internship at Madrasah Aliyah Negeri 1 Banggai, there were some problems in writing. The students found difficulties to start writing. It was because the students were often confused to express their idea in writing. Another problem was that they had low understanding of grammar.

In relation to writing problem, the students need a technique in order to understand the new word easily and achieve the target. The technique that used by the researcher is needed to improve their writing skill. One of the techniques that can make the students find it easy to express their idea is mind mapping. Mind mapping order many keywords in every branch. Relating to the learning writing descriptive text, it is believed that the use of mind mapping can rise the students' ability in writing because mind mapping can dig the students to increase their vocabulary and creativity to arrange sentence and organize ideas readable and understandable text. Based on the explanation above, the problem that will be discussed are: Can Mind Mapping help the students to improve the ability in writing descriptive text in Madrasah Aliyah Negeri 1 Banggai? And how does Mind Mapping improve the students' writing ability in Madrasah Aliyah Negeri 1 Banggai?

\section{a. Writing}

In the general meaning as we know writing is one of important language skills that should be mastered by students. writing is an activity of exploring opinions and ideas into the words. If we have ideas, opinion and everything to explain, writing can be used as an instrument which make someone else understand what we want to explain. It is included the organization of words, phrases, clauses, and sentences into coherent and cohesive paragraphs and texts.

According to Brown (2001) writing is a written product of thinking, drafting and revising that requires specialized skills on how to generate ideas, how to organize them coherently, how to revise a text for clear meaning, how to edit a text for the appropriate grammar, and how to produce a final product. While, Harris (1993) argues that writing is that happen over a period of time, especially if we take into account sometimes extended period of thinking that precede creating an initial draft. In additional, Byrne (1988) believed that writing is an act of forming graphic like making marks on a flat surface of some kind. Writing is a skill that need a process so that ides that have been processed can be expressed through writing. It is needs in teaching-learning process to make the teaching-learning process can be done well.

From the explanation above, the researcher concludes that writing is a way or process of giving information to texts that involved in generating the letters, words and sentences words. By using writing everyone can share their ideas, opinions and feel something that exist in their mind, make other people or reader understand the ideas. language using write that comes from our thought. 


\section{b. The Process of Writing}

Writing some ideas into good writing need a process. Clouse (2004) stated that before begin to write, there are six writing process make a successful writer when their attention, they are: First, generating ideas, establishing purpose, and identifying audience. It is the actions that firstly have to do before start to write. Ideas is needed to make a writing. Purpose should be decided to make writing clear what purpose is written. And then, identifying audience should be paid attention to the writing will be read. Second, Ordering ideas. We may have many ideas we want to share, but we have also to remember that the affect our quality of writing itself. Ordering ideas is needed to make sense our writing whether it is nice or not. Next is writing the first draft. If we compare writing to building construction that should have some planning, writing also has planning and it is called as draft. Furthermore, Revising or improving content, organization, and the expression of ideas. Through revising our writing, we can add some ideas and remove something that not important or have not relation with the topic. In revising, we should be pay attention to the existence and what the contains of our writing. Then, Corrections errors by correcting grammar, spelling, capitalization and punctuation. We need to correct any grammar, spelling, capitalization, and punctuation that becomes our writing well. The last is proof-reading. We have to do the proof-reading in order we can get any errors that may appear in our writing. Proof-reading is done by us as a writer so the idea included do not make changes and the purpose of writing is still achieved to the reader.

\section{c. Assessment of Writing}

The scoring rubric is used to assess the students' writing. The writing evalution system based on the five writing components including content, organisation, vocabulary, language use, and mechanics. According to Jacob et al (1981) the level of students' writing can be described into four categories such as excellent to very good to get four points, good to average to get three points, fair to poor to get two points, and very poor to get one point. Furthermore, the detail explanation from Jacob at all.

Table 1. Aspect of Witing

\begin{tabular}{|c|c|c|c|c|}
\hline $\begin{array}{l}\text { Aspect of } \\
\text { Writing }\end{array}$ & Level & & Score & Criteria \\
\hline \multirow{4}{*}{ Content } & $\begin{array}{l}\text { Excellent } \\
\text { Very Good }\end{array}$ & to & 20 & $\begin{array}{l}\text { Knowledgeable, substantive, thorough } \\
\text { development of thesis, and relevant to } \\
\text { assigned topic }\end{array}$ \\
\hline & $\begin{array}{l}\text { Good } \\
\text { Average }\end{array}$ & to & 15 & $\begin{array}{l}\text { Some knowledge of subject, adequate } \\
\text { range, limited development of thesis, } \\
\text { mostly relevant to topic but lacks } \\
\text { details }\end{array}$ \\
\hline & Fair to Poor & & 10 & $\begin{array}{l}\text { Limited knowledge of subject, little } \\
\text { substance, inadequate development of } \\
\text { topic }\end{array}$ \\
\hline & Very Poor & & 5 & $\begin{array}{l}\text { Does not show knowledge of subject, } \\
\text { non-substantive, non pertinent or not } \\
\text { enough or not enough to evaluate. }\end{array}$ \\
\hline \multirow{2}{*}{$\begin{array}{l}\text { Organisati } \\
\text { on }\end{array}$} & $\begin{array}{l}\text { Excellent } \\
\text { Very Good }\end{array}$ & to & 20 & $\begin{array}{l}\text { Fluent expression, ideas clearly stated } \\
\text { or supported, succinct, well-organized, } \\
\text { logical sequence, cohesive }\end{array}$ \\
\hline & $\begin{array}{l}\text { Good } \\
\text { Average }\end{array}$ & to & 15 & $\begin{array}{l}\text { Somewhat choppy, loosely organized } \\
\text { but mean idea stand out, limited } \\
\text { support, logical but incomplete }\end{array}$ \\
\hline
\end{tabular}




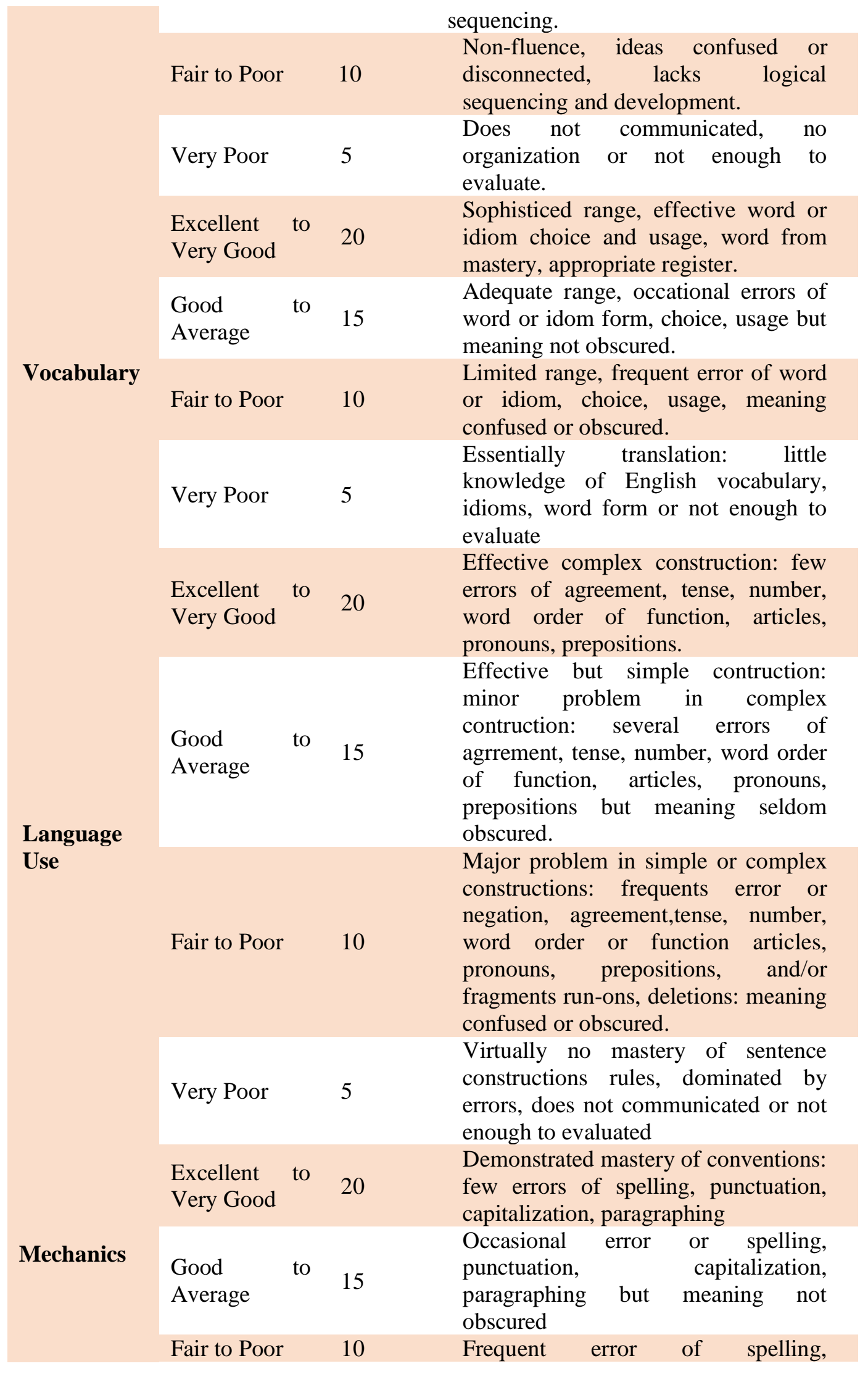




\begin{tabular}{lll} 
& $\begin{array}{l}\text { punctuatuin, capitalization, } \\
\text { paragraphing: poor handwriting, } \\
\text { meaning confused or obscured }\end{array}$ \\
& $\begin{array}{l}\text { No mastery of conversations: } \\
\text { dominated by error of spelling, } \\
\text { very Poor }\end{array}$ & $\begin{array}{l}\text { punctuation, } \\
\text { paragraphing: handwriting illegible or } \\
\text { not to evaluate. }\end{array}$ \\
\hline
\end{tabular}

\section{d. Descriptive text}

Descriptive text is a text that aims to explain or describe a people, animal, situation, event, place or object. Generally, it describes the shape, characteristics, or nature. Using descriptive, the Readers can feel deeply about what they read. According to Gerrot, L. \& Wignell (1994) descriptive text is one of text kind to give information. Descriptive text is when we write description of something with its characteristics and some appearances of that thing. Besides of that, Oshima, A. \& Hogue (1997) argued that description is writing describe something with characteristics and appearances of that things. From those explanation, descriptive text is describing, explaining and telling the details about something like people, place, animal, situation, event, place or object, make the Readers can feel or imagine it because descriptive details enable the readers to visualize elements in the story.

\section{e. $\quad$ Mind Mapping}

Mind Mapping was popularised by Buzan, a British popular psychology author, in 1970s. Mind Mapping is common techniques in English teaching-learning process. Mind mapping involves writing down a central idea and thinking that can help our memory because it enables us to arrange the facts and ideas. Mind mapping ("idea" mapping) has been defined as 'visual, non-linear representations of ideas and their relationships' (Biktimirov \& Nilson, 2006). Mind mapping will help us to understand and remember new information by focussing on the key ideas that are written down, and then looking for branches out and connections between the ideas.

Mind mapping also is a system that uses brain management to open all the hidden brain potency and capacity. Besides, mind mapping is also a learning system that is often used to help students to learn effectively. Mind Mapping can be applied in every aspects of our life. In education, mind mapping commonly used to balance the right and left of brain. The right side of the brain is for creative and visual things and the left side is for rational and logical things.

Buzan (2005: 5) stated that mind mapping has natural organizational structure that radiates from the centre and use lines, symbols, key words, color or imagine according to simple concepts. From the explanations, mind mapping is a graphic way of showing mind idea from the centre radiates related ideas using lines, symbols, key words, color and images. Mind mapping helps a writer to develop their ideas.

\section{f. $\quad$ The Step of Mind Mapping}

According to Buzan (2005: 15 -16) gives seven steps to making a mind mapping. They are first start from centre of the blank paper. It will give the brain freedom to express and explore anything. The second is using a picture as the central idea. It can help to improve the imagination and keep focus on the mind topic or idea. Then, Use multiple colors throughout the mind mapping. Colors are interesting for brain. Coloring pencil will make mind mapping more alive. Next, Connect the mind picture to some branch details. Brain can connect three or four points in one time and it is easier to remember and 
understand. Further step by connecting the branches with curve lines, not straight lines because straight lines will make the brain bored. Use a keyword in every branch. Every single word will encourage the brain to develop it to be a new thought.

\section{Research Method}

Refers to Cresswell (2012) as an expert of research method, this research consists of two variables those were independent variable $(\mathrm{X})$ using mind mapping in teaching writing descriptive text. Then, the dependent variable (Y) students' writing ability. Population of this research were all the tenth grade students in Madrasah Aliyah Negeri (MAN) 1 Banggai. They were 69 students. Researcher chose X science 1 as experimental class and X science 2 as controlled class. This Research was used Quasi-Experimental by using non-equivalent design. The sample technique used in this Quasi-experimental class was purposive sampling that purposed by Sugiyono (2013: 85). It means the researcher selected from the population that would be representative or informative about the topic. The reasons of the researcher chosen because both of the classes had same ability.

The instrument which become the technique in collecting data of this research was a written test. The tests were pre-test and post-test. It was used to know how well the students already mastered in learning writing of descriptive text also to prove the effect of mind mapping technique on students' writing ability in descriptive text.

In analysing the data taken from both classes (the experimental and controlled class), the researcher used scoring rubric to assess students' pre-test and post-test. After that, the researcher analysed using the formula by Gay (2006).

\section{Findings and Discussion}

Based on the research finding which calculated by using the formula from Gay (2006). It can be observed that the scores of students who have been taught descriptive writing using Mind Mapping technique are higher than those who have been taught with mind mapping technique. It means that mind mapping technique is effective on students' writing descriptive text.

The researcher tried to apply mind-mapping technique for students of Madrasah Aliyah Negeri 1 Banggai to make them easier in developing the ideas so they will be helped in organizing their writing. Therefore, many researchers tried to investigate the effective technique for teaching writing. The researcher conducted the research to prove whether Mind Mapping technique is really effective for students in writing descriptive text. Based on this research, Mind Mapping technique is attractive technique which gained students motivation in learning writing. Students become creative and developing their own writing especially writing descriptive text.

Based on the calculation by using some formulas to calculate students' scores in pretest and post-test, the researcher believed that mind mapping technique is effective on students' writing of descriptive text. The result of t-counted is higher than t-table, the score of t-counted was 18.80 and t-table on the degree significance $0.05=1.66792$. The researcher made a conclusion of the hypothesis that $\mathrm{t}$-counted is higher than t-table; 18.80>1.66792. It means that the alternative hypothesis (Ha) of this research had been proven. It assumed that mind mapping technique can improve the students' writing ability in descriptive text of tenth grade students of Madrasah Aliyah Negeri 1 Banggai Thus the alternative hypothesis $(\mathrm{Ha})$ is accepted and the null hypothesis $\left(\mathrm{H}_{0}\right)$ is rejected.

\section{Conclusion}

Based on the research finding and discussion in the previous paragraph, it knows that the students of both classes have never been taught descriptive writing using mind mapping technique before. The researcher conducted the research that the experimental 
class students got higher average scores on the post-test was the fact. After doing the treatment, the students improved their writing used mind mapping technique.

Then the data that has been described from the experimental research of the tenth grade students at Madrasah Aliyah Negeri 1 Banggai, the researcher found that $t_{\text {counted }}$ 18.80 is higher that $t_{\text {table }}$ in both degree of significance 0.05 is 1.66792 . It means that the alternative hypothesis was accepted and the null hypothesis was rejected. Therefore, it can be concluded that mind mapping technique can improve the students' ability of writing descriptive text at tenth grade of Madrasah Aliyah Negeri 1 Banggai in academic year 2019-2020.

Additionally, the researcher would like to suggest that mind Mapping Technique should be applied by English teachers especially for Senior High School students as an alternative technique in teaching writing since it has been proven that Mind Mapping Technique gives influence in learning writing ability. Also, the students should be accustomed to using Mind Mapping Technique so that they will be easier to write the text and more interested in learning writing. The students have to practice a lot in order to enhance their skill in writing. Then, the teacher and the students have significant roles in achieving their success in a subject so that it should be realized that learning has two ways process, not only teacher-centered but also student-center. In other words, the students should be more active in participating in the teaching-learning process. The students are also suggested to keep their motivation and improve their writingmore intensively and seriously not only in the classroom but outside the classroom as well. Finally, for other researchers who are going to conduct the experimental study, this research can be a reference for further analysis related to teaching writing of other kinds of texts not only for learning descriptive text.

\section{References}

Biktimirov, E. N. \& Nilson, L. B. (2006). Show Them the money: Using Mind Mapping in the Introductory Finance Course. Journal of Financial Education, 32(Fall), 7286.

Brown, H. D. (2001). Teaching by Principles an Interactive Approach to Language Pedagogy. San Fransisco: Longman.

Buzan, T. (2005). Buku Pintar Mind Map. Jakarta: Gramedia Pustaka Utama.

Byrne, D. (1988). Teaching Writing Skills. London: Longman.

Clouse, B. F. (2004). The Student Writer (6th ed.). New York: Mc Grow Hill.

Cresswell, J. C. (2012). Education Research, Planning, Conducting and Evaluating Qualitative and Quantitative Research (4th ed.). Boston: Pearson.

Gay, L. R. et al. (2006). Educational Researcher: Competencies for Analysis and Applications. USA: Pearson.

Gerrot, L. \& Wignell, P. (1994). Making Sense of Functional Grammar. Australia: Antipodean Educatinal Enterprises.

Harris, J. (1993). Introducing Writing. London: Longman.

Jacob, H. et all. (1981). Testing ESL Composition: A partial Approach. Massachusetts: Newbury House.

Oshima, A. \& Hogue, A. (1997). Introduction to Academic Writing. New York: Longman.

Sugiyono. (2013). Metode Penelitian: Kuantitatif, Kualitatif, dan R\&D. Bandung: Alfabeta. 